\title{
Immediate effect of Dallmer Hoof Clogs on head and pelvic asymmetry using body mounted inertial sensors
}

\author{
Matthias Johannes Rettig and Christoph J. Lischer \\ Equine Clinic at the Faculty of Veterinary Medicine, Free University of Berlin, Berlin, Germany
}

\begin{abstract}
Summary: From different reasons the hoofs of the horse should be protected in a manner that prevents easy frequent removal. The aim of this study was to assess one such method of temporary hoof covering, a hoof clog, to determine if application in horses trotting over hard ground affected vertical head and pelvic movement asymmetry measures of forelimb and hind limb lameness, compared to the normal shod and unshod (barefoot and just trimmed) condition. We were particularly interested in determining whether the hoof clog prevented any lameness that might develop in horses trotting barefoot on hard surface immediately after trimming. Twenty horses were randomly obtained from a riding school herd and evaluated objectively with their regular shoeing, barefoot and with a clogs applied using body mounted inertial sensors. Overall there were no significant differences in either group between treatments (regular shoeing, trimmed and unshod, clogs). Results of this study support the contention that applications of these hoof clogs do not cause forelimb or hind limb lameness, are well tolerated, and may decrease concussion when trotting on hard ground.
\end{abstract}

Keywords: horse / inertial sensors system / hoof clogs / barefoot / lameness examination

Citation: Rettig M. J. , Lischer C. (2016) Immediate effect of Dallmer Hoof Clogs on head and pelvic asymmetry using body mounted inertial sensors. Pferdeheilkunde 32, 212-216

Correspondence: Dr. Matthias J. Rettig, Klinik für Pferde, Freie Universität Berlin, Oertzenweg 19b, 14163 Berlin, Germany; e-mail: matthias.rettig@fu-berlin.de

\section{Introduction}

In feral horses in their natural environments there is balance between hoof growth and wear. Nutritional, climatic, and surface abrasion conditions keep the hooves flexible but hard, and in a shape that is biomechanically optimal (Hampson et. al. 2010, Jackson 1997, Strasser 2000). However, domesticated horses are frequently kept in artificial environments, and are potentially exposed to extreme biomechanical conditions (Dyhre-Poulsen 1994). Also, wet environments common to many parts of the world weaken hoof wall structure and integrity (Back 2013, Friedrich 1931, Leisering et al. 1982, Ruthe 1988, Schwendimann 1937). In some breeds selective reproduction has resulted in larger bodies on smaller hooves. Extreme forces of impact or loading, even on a well-formed and healthy hoof wall, can be experienced in the domesticated horse, for example, riding on completely inelastic surfaces like concrete and asphalt, or simply stepping on a rock when moving at high speed. These conditions even at momentary or for intermittent periods of time may adversely affect sensitive hoof tissues. As a result many domesticated horses are shod, usually by nailing on a piece of metal to the bottom of the hoof wall, or in some cases, fixing it to the bottom of the hoof with glue (Back 2013, Clayton 2011, Curtis 2006, Hertsch et al. 1997, Humphrey 1995, Leisering et al. 1982, Leslie 1977, Möller 1915, Schwendimann 1937).

Fixing a protective layer to the bottom of the horse's hoof wall in a manner that prevents easy frequent removal has obvious drawbacks. Imagine never taking your shoes off. The bottom of the foot is always protected. However, exposure of the bottom of the hoof wall to normal physiologic conditions and loads, which are beneficial, is also prevented (Hinterhofer 2006). A better approach, if reasonably convenient and inex- pensive, would be to protect the bottom of the foot when necessary and to expose it when not. Several commercial brands of slip or tie-on hoof protection have been marketed (Hertsch et al 1997).

The aim of this study was to assess one such method of temporary hoof covering, a hoof clog (Figure 1), to determine if application in horses trotting over hard ground affected vertical head and pelvic movement asymmetry measures of forelimb and hind limb lameness, compared to the normal shod and unshod (barefoot and just trimmed) condition. We were particularly interested in determining whether the hoof clog prevented any lameness that might develop in horses trotting barefoot on hard surface immediately after trimming.

\section{Materials and Methods}

Twenty-three horses (5 Warmbloods, 4 Arabians, 10 Ponies (German Riding Pony), 2 Trotters, 1 Haflinger and 1 Norwegian), with a mean weight of $415 \mathrm{~kg}(220-600 \mathrm{~kg})$ and age of 18 years (4-29 years) were randomly obtained from a riding school herd of around eighty horses and ponies. Three Warmbloods had to be removed from the study because their foot size exceeded the available sizes of hoof clogs being tested. None of the horses selected had worn the hoof clogs before. The horse's weight was recorded using a weight tape. The size of the horse and their routine shoeing were unknown prior to arrival but all horses were examined clinically to ensure that only clinically healthy horses (standard physical examination for clinical health) were included. All horses were further evaluated for lameness in a brief orthopedic examination (walk and trot) by an experienced veterinarian twenty minutes 
post arrival at the clinic. The presence of lameness was not a prerequisite for inclusion or exclusion, but degree of lameness was used to exclude obviously lame horses ( $>2 / 5$ on the AAEP scale). Horses fulfilling the inclusion criteria were then randomly split into two groups by throwing a dice.

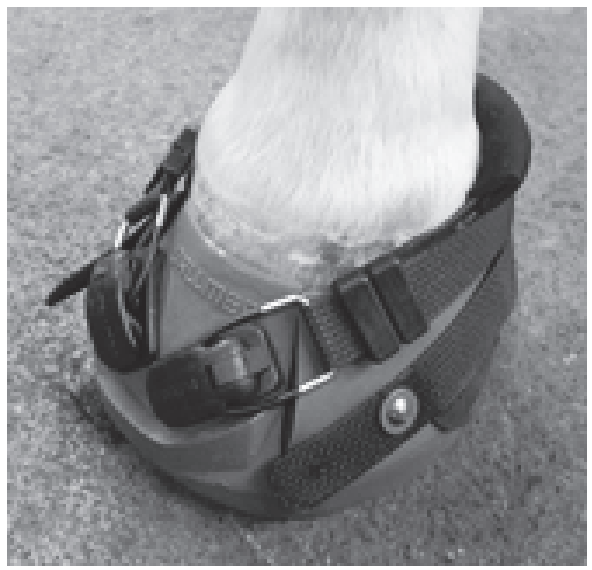

Fig.1 Right forelimb with a Dallmer-Hoof Clog applied

After group assignment all horses were evaluated objectively on a first trial (trial 1) with their existing shoeing method, which included either shoes on all 4 feet $(n=10)$, shoes on the front but not hind feet $(n=6)$, and unshod on all feet $(n=4)$. Evaluation was with an objective method using bodymounted inertial sensors that has been described previously. Briefly, each horse was instrumented with a uni-axial accelerometer sensor attached to the head at the poll, a uni-axial accelerometer sensor attached to the dorsum of the pelvis between the tubera sacralia, and a uni-axial gyroscope attached to the dorsal surface of the right forelimb pastern (Keegan 2010, Keegan et al. 2011 , Keegan et al. 2012, Keegan et al. 2013, Marshall et al. 2012, McCracken et al 2012). The movement of the horse was assessed while trotting in a straight line on a hard ground for approximately 50 meters, which sampled between 25 and 50 strides depending on the size of the horse. The horse was lead and restrained by the same person at each evaluation time.

\section{Assess gait asymmetry}

Objective measurements of forelimb and hind limb movement were provided by the body-mounted inertial sensor system. For forelimb lameness, the head movement asymmetry has previously been reported as the vector sum (VS) of maximum $\left(\mathrm{H}_{\max }\right)$ and minimum $\left(\mathrm{H}_{\min }\right)$ head height difference between the right and left halves of each forelimb stride in millimeters (mm) (Figure 2). This represents an overall measurement of the head movement asymmetry in both upward and downward direction. The side of lameness is determined by the sign of minimum head height difference, with a negative value indicating left forelimb lameness and a positive value indicating right forelimb lameness. In this 2-component model of head movement evaluation $\mathrm{H}_{\text {min }}$ and $\mathrm{H}_{\max }$ are conceptually related and cannot be evaluated separately. Therefore VS was the single dependent variable of head movement asymmetry for evaluation of forelimb lameness.

$$
(V S)=\sqrt{H D_{\max }{ }^{2}+H D_{\min }{ }^{2}}
$$

For hind limb lameness, pelvic movement asymmetry has been reported as the minimum $\left(\mathrm{P}_{\min }\right)$ and maximum $\left(\mathrm{P}_{\max }\right)$ pelvis height differences in millimeters $(\mathrm{mm})$ between the left and right halves of the stride. $P_{\min }$ is associated with a decreased downward movement in the first half of stance of the hind limbs and $P_{\text {max }}$ with a decreased upward movement during the second half of stance of the hind limbs. Negative values of $P_{\text {max }}$ and $P_{\min }$ are defined as asymmetric pelvic movement due to left hind limb lameness and positive values indicate asymmetric pelvic movement due to right hind limb lameness. In this 1component model of pelvic movement evaluation of $P_{\min }$ and $P_{\text {max }}$ are conceptually un-related and therefore evaluated separately as dependent variables for hind limb lameness.

The approximate values $\left(8.5 \mathrm{~mm}\right.$ for $V S$ and $\pm 3 \mathrm{~mm}$ for $P_{\text {max }}$ and $P_{\min }$ ) for clinically important difference and thresholds between sound and lame conditions are based on the $95 \%$ confidence intervals for repeatability for these asymmetry measures, which have been determined previously by comparing to expert subjective evaluation in a large number of horses with varying degrees of forelimb and hind limb lameness (Keegan et al. 2013).

After the first trial the shoes were taken of if present and all four feet trimmed by an experienced farrier. Each hoof was measured at its widest point in a horizontal plane. Using a chart supplied by the manufacturer the farrier fitted and applied the hoof clogs (for group 2 horses) to all 4 feet before evaluation. In group 1 horses, before the 3rd trial.

Horses assigned to group 1 were re-evaluated barefoot (trial 2 , treatment 2) and then again after application of the correct size hoof clog to all 4 feet (trial 3, treatment 3). Horses in group 2 were re-evaluated first after trimming, wearing the hoof clog on all 4 feet (trial 2, treatment 3), and then again barefoot (trial 3, treatment 2).

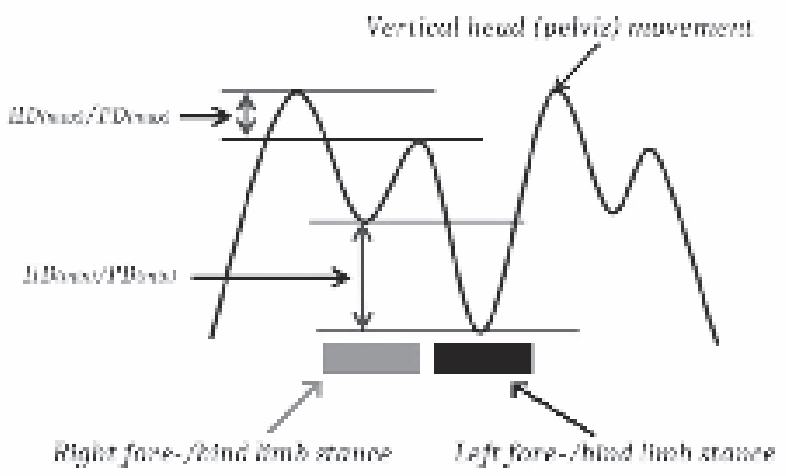

Fig. 2 Forelimb and hind limb lameness measured using bodymounted inertial sensors. $H D_{\text {max }}$ is the vertical head height maximum preceding right forelimb stance minus the same preceding left forelimb stance. $H D_{\text {min }}$ is vertical head height minimum during right forelimb stance minus the same during left forelimb stance. VS measure the combined asymmetric upward and downward, respectively, vertical head movement that is associated with forelimb lameness. $\mathrm{PD}_{\max }$ is vertical pelvic height maximum preceding right hind limb stance minus the same preceding left hind limb stance. $\mathrm{PD}_{\min }$ is vertical pelvic height minimum during right hind limb stance minus the same during left hindlimb stance. $\mathrm{PD}_{\min }$ and $\mathrm{PD}_{\max }$ measure separately the asymmetric upward and downward vertical pelvic movement that is associated with hind limb lameness. (Rettig et al. 2015, with permission of Equine Vet. J.) 
Before collecting data in each trial, horses were trotted in hand about 50 meters to adapt to the new foot treatment. Each shoe was removed, the hoof was trimmed, and the hoof clog applied by the same experienced farrier. The measurements for the correctly fitted clog were taken by an experienced veterinarian and farrier and the boot size was chosen using the supplier's provided scale (Table 1).

\section{Data Analysis}

Distribution of measured results (VS, Pmax, Pmin) in each group and treatment were evaluated for normality using the Shapiro-Wilk Test. Differences between times for each group and for both groups were evaluated with either Friedman's test or a one-way, repeated measures ANOVA depending on the shape of the distributions. Differences between times for each group were considered significant at $\alpha \geq 0.05$. Statistical analyses and plotting were performed with StatsDirect Medical Statistics Software.

\section{Results}

Starting out in group 1 there were 2 horses that had head and pelvic asymmetry measures indicative of no lameness, $1 \mathrm{had}$ head movement asymmetry indicative of right forelimb lameness, and 7 had pelvic asymmetry measures indicative of hind limb lameness ( $3 \mathrm{RH}, 4 \mathrm{LH})$. Starting out in group 2 there were 2 horses that had head and pelvic asymmetry measures indicative of no lameness, 2 had head movement asymmetry of forelimb lameness (1 RF, 1 LF), and 6 that had pelvic asymmetry measures indicative of hind limb lameness (1 RH, $5 \mathrm{LH})$.

Using the threshold values of VS, $P_{\max }$ and $P_{\min }$ to signal significant change in lameness, barefoot trotting on hard ground after trimming (treatment 2) resulted in no change in lameness in 6 horses for both groups 1 (barefoot and trimmed evaluated first first) and group 2 (clog application evaluated first) horses. Four horses in group 1 and 2 horses in group 2 either developed or had a worsening in lameness when evaluated barefoot after trimming. Two horses in group 2 improved compared to before removal of shoes when evaluated barefoot after trimming, one in a forelimb lameness and one in a hind limb lameness, and both of these horses had shoes on all 4 feet when evaluated at the beginning of the experiment.

Evaluation with the hoof clogs on resulted in either no change or an improvement in lameness in 5 horses in group 1 (barefoot and trimmed evaluated first) and in 9 horses in group 2 (clog application evaluated first). Five horses in group 1, but

\begin{tabular}{ccc}
\hline $\begin{array}{l}\text { Table } 1 \\
\text { mm for fore and hindlimb }\end{array}$ & \multicolumn{2}{c}{ Size of hoof shoe regarding to width of horses foot in } \\
\hline \multicolumn{3}{c}{ Size - Scale } \\
\hline \multirow{2}{*}{ Size } & \multicolumn{1}{c}{ Width of hoof in mm } \\
\cline { 2 - 3 } & Forequarters & Hindquarters \\
\hline 1 & $100-109$ & $100-109$ \\
3 & $110-124$ & $110-120$ \\
4 & $125-134$ & $121-130$ \\
\hline
\end{tabular}

only 1 horse in group 2, either developed lameness or had a worsening in lameness when evaluated with the clogs.

Measures for VS assessing forelimb lameness at most times were not normally distributed, so evaluation of differences between times were assessed with the non-parametric Friedman's test. Measures of $P_{\max }$ and $P_{\min }$ for all times for both groups were normally distributed, so evaluation of differences between times were assessed with the parametric one-way, repeated measure ANOVA.

Overall horses there were no significant differences in VS, Pmax, or Pmin for either group between treatments (regular shoeing, trimmed and unshod, clogs) or for both groups considered together. There was trend $(p=0.06)$ in group 1 (barefoot and trimmed evaluated first) for $\mathrm{P}_{\min }$ to be higher when horses were evaluated barefoot after trimming (figure 3). The same was not found in group 2 horses (figure 4). There was also a slight trend $(p=0.10)$ in group 2 horses for $P_{\text {max }}$ to be higher before removal of shoes at the beginning of the experiment, but the same was not seen in group 1 horses.

\section{Discussion}

The purpose of this study was to objectively evaluate whether applying hoof clogs to the freshly trimmed foot prevented (or

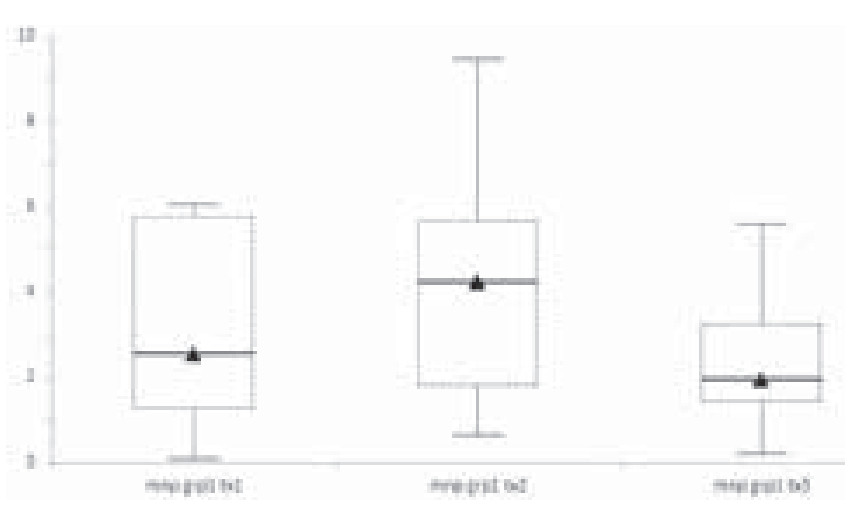

Fig. 3 Pmin of horses in group 1, first being with their normal soeing (tx 1$)$, followed by barefoot (tx 2$)$ and protective hoof shoe (†x3).

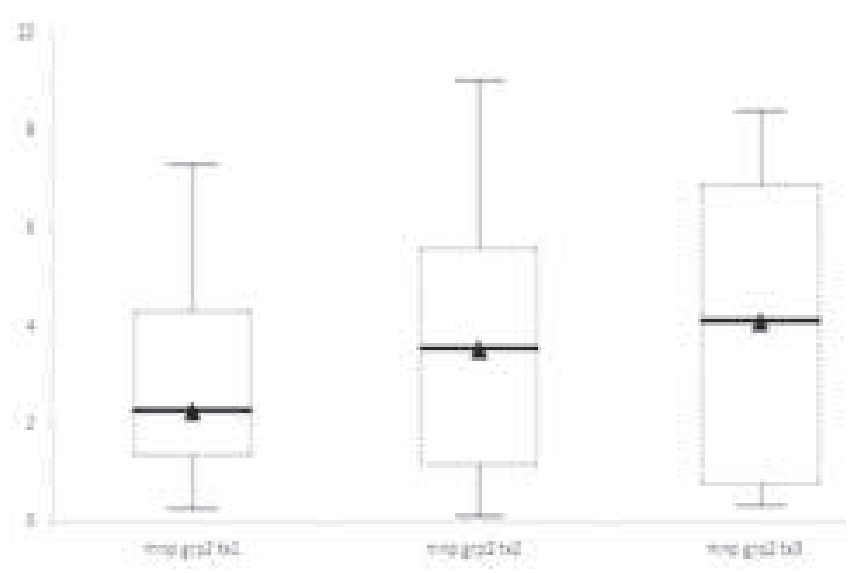

Fig. 4 Pmin of horses in group 2, first being with their normal soeing (tx 1), followed by protective hoof shoe ( $t \times 2)$ and barefoot ( $t \times 3)$ 
caused) forelimb or hind limb lameness. Although mean level of lameness as measured by head and pelvic movement asymmetry was not significantly different between any of the treatment (with shoes, barefoot after trimming, and with clogs) in any group, we did find some interesting trends when clogs were applied to the freshly trimmed foot and evaluated before allowing the horse to trot on a hard surface. More horses were either unchanged in lameness or improved when evaluated wearing the clogs. More horses either developed lameness or had worsening in existing lameness if they were allowed to trot barefoot after trimming.

The hoof clogs were easy to fit and apply for an experienced farrier, and once fitted they were easy to apply and remove. After some brief training, students without any experience in hoof shoe application, could quickly and correctly apply the clogs. All horses fitted with the clogs were trotted for 50 meters before they were re-evaluated objectively. Subjectively, a few horses seemed to have mild increased movement of the limbs for about 5-10 strides, but then all seemed to tolerate the clogs and trot normally within a few meters.

Although not statistically significant there was a trend for $\mathrm{P}_{\text {min }}$ to be higher in group 2 horses when evaluated barefoot after trimming, and more horses either developed lameness or had a worsening in lameness when evaluated barefoot after trimming. $P_{\min }$ is a measure of the impact component of hind limb lameness and pain or sensitivity on impact of the hind limbs may be caused or exacerbated by allowing exercise on hard ground while barefoot immediately after trimming. The application of the hoof clogs may ameliorate this by protecting the bottom of the foot.

Though not statistically significant there was also a small trend for higher $\mathrm{P}_{\max }$ in the horses before removing the shoes. $P_{\text {max }}$ is a measure of asymmetry hind limb pushoff. Hind limb pushoff effectiveness likely is improved with good hind limb traction and the steel shoes on the asphalt surface may cause slight slippage during pushoff of the hind limbs.

In this study only 10 horses per group were evaluated and no statistically significant effects of the hoof clogs were found.

\section{Conclusion}

Results of this study support the contention that applications of these hoof clogs do not cause forelimb or hind limb lameness, are well tolerated, and may decrease concussion when trotting on hard ground. Additional studies with larger numbers of horses should be performed, particularly with groups of either completely sound horses or horses with consistent lameness in either the forelimb or hind limb, especially if the lameness focus is within the foot or distal limb joints. Also, other studies in which the horses are fitted and wearing the clogs, and are subjected to exercise and ridden on different surfaces, while traveling in a circle should be conducted.

\section{Animal welfare statement}

This study was approved by the Ethics Committee of the Free University of Berlin. Az L0294/13

\section{Manufacturer's addresses}

a Dallmer Clog, Salzhausen-Putensen, Germany

\section{Source of funding}

The hoof shoes used in the study were provided by Dallmer.

\section{Conflict of Interest Statement}

No conflicts of interest have been declared.

\section{References}

Back W., Clayton H. (2013) The role of the hoof and shoeing, Equine Locomotion, 2nd Edition, Saunders, Elsevier

Clayton H., Gray S., Kaiser L., Bowker R. (2011) Effects of barefoot trimming on hoof morphology, Aust. Vet. J. 89, 305-31 1

Curtis S. (2006) Corrective Farriery - A Textbook of Remedial Horseshoing. Newmarket, R \& W Publications

Dyhre-Poulsen P., Smedegaard H., Roed J., Korsgaard E. (1994) Equine hoof function investigated by pressure transducers inside the hoof and accelerometers mounted on the first phalanx. Equine Vet. J. 26, 362-366

Friedrich H. (1931) Über das Wachstum und die Abreibung der Hornwand des Pferdehufes. Berl. Tierärztl. Wschr. 47, 20-21

Hampson B., Ramsey G., Macintosh A., Mills P., De Laat M., Pollitt C. (2010) Morphometry and abnormalities of the feet of Kaimanawa feral horses in New Zealand. Aust. Vet. J. 88, 124-131

Hertsch B., Höppner S., Dallmer H. (1997) Der Huf und sein nageloser Hufschutz. Warendorf, Fn-Verlag

Jackson J. (1997) Natural Horse: Foundations for Natural Horsemanship, 2nd Edition, Star Ridge Publications

Hinterhofer C., Weißbacher N., Buchner H., Peham C., Stanek C. (2006) Bewegungsanalyse der Hornwand, der Sohne und des Strahls unter zyklischer Belastung in vitro: Verformung des Pferdehufes in Abhängigkeit vom Beschlag und barfuß Pferdeheilkunde 22, $314-319$

Humphrey M. (1995) The Horse Shoeing Book. Allen J. A., London

Keegan K. (2010) The Lameness Locator (wireless inertial sensors for detection of lameness in horses). WVOC 2010, Bologna, Italy

Keegan K., Kramer J., Yonezawa Y., Maki H., Pai P., Dent E., Kellerman T., Wilson D., Reed S. (2011). Assessment of repeatability of a wireless, inertial sensor-based lameness evaluation system for horses. Am. J. Vet. Res. 72, 1156-1163

Keegan K., MacAllister C., Wilson D., Gedon C., Kramer J., Yonezawa Y., Maki H.,Pai P. (2012) Comparison of an inertial sensor system with a stationary force plate for evaluation of horses with bilateral forelimb lameness. Am. J. Vet. Res. 73, 368-374

Keegan K., Wilson D., Kramer J., Reed S., Yonezawa Y., Maki H., Pai P., Lopez M. (2013) Comparison of a body-mounted inertial sensor system-based method with subjective evaluation for detection of lameness in horses. Am. J. Vet. Res. 74, 17-24

Leisering A., Hartmann H. (1982). Der Fuß des Pferdes in Rücksicht auf Bau, Verrichtungen und Hufbeschlag. Schoenfeld's Verlagsbuchhandlung, Dresden

Leslie E. (1977) Horseshoeing Theory and Hoof Care. Lea and Febiger, Philadelphia

Marshall J., Lund D., Voute L. (2012) Use of a wireless, inertial sensor-based system to objectively evaluate flexion tests in the horse. Equine Vet. J. Suppl 43, 8-11

McCracken M., Kramer J., Keegan K., Lopes M., Wilson D., Reed S., LaCarrubba A., Rasch M. (2012) Comparison of an inertial sensor system of lameness quantification with subjective lameness evaluation. Equine Vet. J. 44, 652-656 
Möller H. (1915) Hufpflege, Hufschutz und -beschlag. Parey Verlag, Berlin

Rettig M., Leelamankong P., Rungsri P., Lischer C. (2015) Effect of Sedation on fore- and hindlimb lameness evaluation using body mounted inertial sensors. Equine Vet. J., DOI: 10.1111 /evj.12463 Ruthe H. (1988) Der Huf. Stuttgart, Fischer Verlag

Strasser H. (2000) Shoeing: A Necessary Evil?, Sabine Kells Publisher Schwendimann F. (1937) Leitfaden des Hufbeschlages. Zimmermann Verlag, Bern

\section{Erweiterte Zusammenfassung}

\section{Objektive Evaluierung des unmittelbaren Effekts eines Hufschuhs auf den Bewegungsablauf von Pferden mittels eines Sensor-Systems}

Bei freilebenden Pferden in ihrer natürlichen Umgebung besteht eine Balance zwischen der Abnutzung der Hufe und dem Hornwachstum. Die Nahrung, das Klima, sowie der Untergrund führen bei ihnen zu einem flexiblen aber harten Huf, welcher biomechanisch optimal angepasst ist. Die Haltung domestizierter Pferde auf unnatürlichem Untergrund verlangt nicht selten extreme biomechanische Voraussetzungen. In einigen Rassen hat die selektive Zucht zu relativ großen Körpern und im Verhältnis hierzu kleinen Hufen geführt. Extreme Belastungen können selbst bei gesunde Hufen beobachtet werden, wenn Pferde auf vollständig unelastischen Böden, wie zum Beispiel Asphalt bewegt werden. Selbst eine zeitlich begrenzte Belastung unter diesen Umständen kann sich auf die sensiblen Strukturen des Hufes auswirken, was dazu führt, dass die meisten domestizierten Pferde in unseren Breitengraden beschlagen sind. Um den Huf temporär schützen zu können, wenn die Gegebenheiten es erfordern und selbigen nicht mit einen permanenten Hufbeschlag zu versehen sind seit einigen Jahren mehrere Hufschuhe-Systeme auf dem Markt verfügbar. Der Grund für diese Studie war es, ein solches temporäres Hufschuh-System zu testen und objektiv zu evaluieren, ob selbiges die messbaren Parameter im Bereich Kopf- und Kruppenasymmetrie (Lahmheit) beeinflussen würde, wenn man es mit dem, gängigen' Beschlag des jeweiligen Pferdes sowie ,barfuß' vergleichen würde, wenn das entsprechende Hufschuh-System unmittelbar nach dem Abnehmen der Eisen und dem Ausschneiden des Hufes aufgebracht wird.

Zwanzig Pferde wurden zufällig aus seiner Herde ausgewählt und klinisch auf ihren Gesundheitszustand überprüft um ausschließlich klinisch gesunde Pferde innerhalb der Studie zu haben. Alle Pferde wurden zudem von einem erfahrenen Tierarzt orthopädisch untersucht. Das Vorliegen einer Lahmheit war dabei kein Ein- bzw. Ausschlusskriterium jedoch wurde sichergestellt, dass kein Pferd mit einer Lahmheit $>2 / 5$ (AAEP Richtlinie) in die Studie aufgenommen wurde. Keines der Pferde hatte jemals zuvor Hufschuhe angepasst bzw. getragen. Pferde, welche die Kriterien erfüllten wurden nach einem Zufallsprinzip in zwei Gruppen eingeteilt und in einer ersten Messung mit ihrem normalen ,Beschlag' evaluiert. Unter normalem Beschlag wurde die Beschaffenheit des Hufes im normalen Alltag des Pferdes gesehen, wobei es sich entweder um Hufeisen an allen 4 Hufen, um Hufeisen nur an den Vordergliedmaßen oder um unbeschlagene Hufe handelte. Die Messung wurde mittels einem erprobten Sensor-System durchgeführt. Die Pferde wurden zur Evaluierung auf einer graden Linie für ca. $50 \mathrm{~m}$ getrabt, hierbei wurde darauf Wert gelegt, dass die Pferde zu jedem Zeitpunkt der Untersuchung von derselben Person vorgetrabt wurden. Nach der ersten Messung wurden die Eisen (wenn vorhanden) abgenommen, die Hufe ausgeschnitten und hergerichtet. Jeder Huf wurde nach Herstellerangaben vermessen und der entsprechende Huf-Schuh für Vorder- wie auch Hintergliedmaße ausgewählt. Pferde in Gruppe 1 wurden nach dem Abnehmen der Hufeisen zunächst barfuß vorgetrabt und mittels Sensor System gemessen. Anschließend wurden die entsprechenden HufSchuhe an allen vier Hufen angebracht. In einer dritten Messung wurde das Pferd erneut evaluiert.Pferden in Gruppe 2 wurde nach der initialen Messung die Eisen abgenommen, die Hufe ausgeschnitten und entsprechende Hufschuhe angepasst. Die Pferde wurden zunächst mit Hufschuhen und im Anschluss barfuß vorgetrabt und gemessen. Vor jeder Messung wurde das Pferd mit der veränderten ,Hufbeschaffenheit' für 50 Meter getrabt um eine kurze Gewöhnung an die veränderten Verhältnisse zu ermöglichen. Jeder Huf wurde vom selben erfahrenen Hufschmied bearbeitet und die HufSchuhe entsprechend der Vorgaben angebracht.

Die Evaluierung der Hintergliedmaße zeigte keinen signifikanten Unterschied zwischen Pferden mit ihrem normalen Beschlag und Pferden, welche barfuß oder mit Huf-Schuhen getrabt wurden. Auch die Messung der Vordergliedmaße ergab keinen signifikanten Unterschied betreffend der messbaren Parameter (Lahmheit) der Pferde mit ihrem ,normalen' Hufbeschlag im Vergleich zu barfuß oder mit Huf-Schuhen. Wenngleich keine signifikanten Unterschiede festgemacht werden konnten, so war doch ein leichter Trend feststellbar. Pferde, die nach dem Ausschneiden mittels Huf-Schuh getrabt wurden, zeigten entweder keine Veränderung oder eine leichte Verbesserung der messbaren Parametern (Lahmheit), wohingegen Pferde, die unmittelbar nach dem Ausschneiden getrabt wurden eine leichte Verschlechterung der messbaren Parameter zeigten.

Die Huf-Schuhe waren für einen erfahrenen Schmied leicht anzupassen und wenn sie korrekt eingestellt waren leicht anzubringen und abzunehmen. Subjektiv zeigten einige Pferde unmittelbar nach dem Anbringen der Hufschuhe für wenige Schritte ein vermehrtes Anheben der Beine, jedoch tolerierten alle Probanden die Hufschuhe nach wenigen Metern problemlos.

Die Ergebnisse dieser Studie bekräftigen die Annahme, dass Hufschuhe keine Lahmheit im Bereich der Vorder- oder Hintergliedmaße verursachen, gut toleriert werden und eventuell die Erschütterung im Trab auf hartem Boden reduzieren. Weitere Studien mit einer größeren Anzahl an Probanden, insbesondere mit ausschließlich lahmfreien oder lahmen Pferden wären sinnvoll, vor allem wenn es sich um diagnostizierte Lahmheiten aus dem Bereich des Hufes handeln würde. Weiterhin wäre eine Untersuchung von Pferden mit Hufschuhen unter dem Reiter sowie auf verschiedenen Böden und auf dem Zirkel als ein weiterer Schritt möglich.

Schlüsselwörter: Pferd / Sensor System / Huf-Schuh / barfuß, /Lahmheits-Untersuchung. 